\title{
認定医ケースプレゼンテーション抄録
}

\author{
磁性アタッチメントを用いたインプラント・オーバーデンチャー症例 \\ 山縣 徹哉
}

\section{A Case Report of Implant Overdenture Using Magnetic Attachment}

\section{Yamagata Tetsuya}

\section{I. 症例の概要}

患 者：62 歳, 女性.

初 診：1999 年 8 月 4 日.

主 訴: 義歯が緩く浮きあがる。

既往歴：特記事項なし。

現病歴：1983 年より $\underline{7+7}, \overline{7+7}$ 欠損に全部床 義歯を使用してきたが, 下顎義歯のさらなる安定を希 望され，1989 年に下顎オトガイ孔間にインプラント 体（カルシテック製インテグラル ${ }^{\mathrm{TM}} 13.0 \mathrm{~mm}$, 中 $3.25 \mathrm{~mm}) 4$ 本を埋入した. 1990 年に O-Ring と 内冠タイプのアタッチメントを併用してオーバーデン チャーを装着した。以後，アタッチメント部の緩みや 維持力の低下が続いたが, 調整により安定が得られた ので，1997 年にリコールとした。その後，今回の主 訴で来院した（図 1 )。

現 症：O-Ring アタッチメントの劣化と粘膜面不 適合および人工歯の咬耗が認められた。

\section{II. 診断と治療方針}

診 断：アタッチメントの選択不適および下顎義歯 の不適合.

治療方針：リジッドな特性のミリングバーアタッチ メントと第三世代の磁性アタッチメントを併用した構 造に変更する ${ }^{1}$. 経年的変化に対応するため, リベー スや修理の際，アタッチメントとオーバーデンチャー

昭和大学歯学部高齢者歯科学教室

Department of Geriatric Dentistry, Showa University School of Dentistry
の位置関係を確認できるように，マグネット相当部の 義歯のメタルフレームを穴あき型とする.

\section{III. 治療内容}

1999 年に磁性アタッチメントによるバー連結型の アタッチメントに変更し，オーバーデンチャーを新製 装着した（図 2).アタッチメントの維持力は O-Ring 2 個で 900 g であったが，マグネット（マグフィッ 卜 $^{\mathrm{TM}} \mathrm{EX} 600 \mathrm{~W}$ ，ジーシー） 5 個に変更したので, 3 $\mathrm{kg}$ と増加した。 また O-Ring のゴムの劣化による維 持力の早期低下は, マグネットで持続的に維持が発揮 され防止された。 また，アタッチメントの交換回数が 少なくすむため, 来院回数が減少した.アタッチメン トの支持力不足は, バー上面で負担する構造でインプ ラント支持の割合を増加させた。アタッチメントの緩 みは連結型のバーで防止された。予後良好となり 6 力 月ごとの定期診査とした。

\section{IV. 経過観察と考察}

バーアタッチメントおよびオーバーデンチャーを新 製装着後, 定期診査には応じなかったが, 2002 年に 上顎義歯の人工歯脱離扝よび下顎義歯の粘膜面不適 合, マグネットの吸着力低下が認められた. 人工歯脱 離を修理しマグネットを交換した。粘膜面不適合部を 粘膜調整材でダイナミック印象後, 咬合圧でウォッ シュ印象し間接リベースを行った（図 $3 \mathrm{a}, \mathrm{b}$ ). 予後 良好となり 3 カ月ごとの定期診査とした.

患者の主観的評価を満足度と咀嚼評価で行った2). 旧義歯の満足度は 65 点で, 新義歯は 90 点であったの 

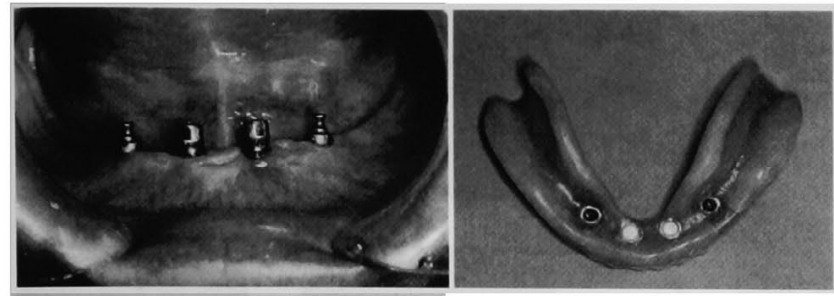

図 1 Intraoral view at the first visit and mandibular overdenture 初診時の口腔内観と下蕷オーバーデンチャー
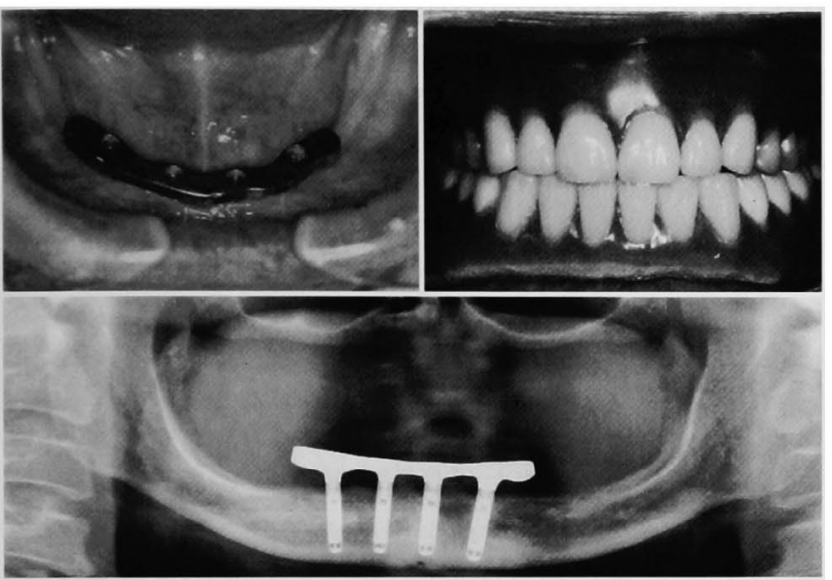

図 2 Intraoral views and orthopantomography after prosthetic treatment

補綴治療後の口腔内写真とパノラマX線写真

で大幅な満足度の増加が認められた。また，咀嚼評価 は旧義歯および新義歯修理前，修理後すべて 75 点で 変化は認められなかった。

本アタッチメントの利点は, バーアタッチメントと

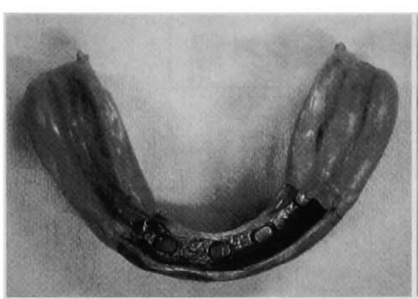

a

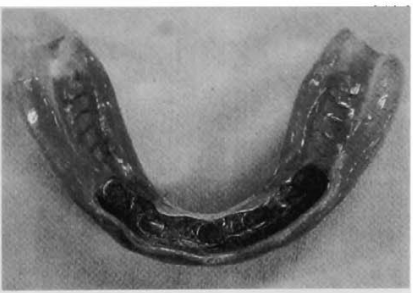

b
図 3 Implant overdenture appliance at three years after treatment

a : Bite pressure impression

$\mathrm{b}:$ Indirect rebase

補綴治療終了 3 年後のインプラントオーバーデンチャー a : 咬合圧印象

$\mathrm{b}$ ：間接リベース

メタルフレームの適合の確認が容易であり, 咬合採得 が確実に行える点で, 臨床的には着脱が容易, 支持力 が大きい点である，さらに，修理も簡便かつ確実に行 える点である。このようなことから本アタッチメント に変更したことは, 有効な手段であったと思われる. 今後, 定期的なリコールを徹底する必要があると思わ れた.

\section{文献}

1）瀬沼壽尉, 山縣徽哉, 佐藤裕二ほか. 磁性バーアタッチメント を用いたインプラントオーバーデンチャー症例. 日ロ腔インプ ラント誌 $16: 295-299,2003$.

2) Sato Y, Hamada S, Akagawa $Y$ et al. A method for quantifying overall satisfaction of complete denture patients. J Oral Rehabil $27: 952-957,2000$. 